\title{
Correction to: Mechanics of the small punch test: a review and qualification of additive manufacturing materials
}

\author{
Jonathan Torres $^{1, *}$ (D) and Ali P. Gordon ${ }^{2}$ \\ ${ }^{1}$ Bucknell University, Lewisburg, $P A$, USA \\ ${ }^{2}$ University of Central Florida, Orlando, FL, USA
}

Published online:

12 April 2021

(C) Springer Science+Business

Media, LLC, part of Springer

Nature 2021

\section{Correction to: J Mater Sci (2021) 56:10707-10744 https://doi.org/10.1007/s10853-021-05929-8}

The article Mechanics of the small punch test: a review and qualification of additive manufacturing materials, written by Jonathan Torres and Ali P. Gordon, was originally published Online First without Open Access. After publication in volume 56, issue 18, page 10707-10744 the authors decided to opt for Open Choice and to make the article an Open Access publication. Therefore, the copyright of the article has been changed to (c) The Author(s) 2021 and the article is forthwith distributed under the terms of the Creative Commons Attribution.
Open Access This article is licensed under a Creative Commons Attribution 4.0 International License, which permits use, sharing, adaptation, distribution and reproduction in any medium or format, as long as you give appropriate credit to the original author(s) and the source, provide a link to the Creative Commons licence, and indicate if changes were made. The images or other third party material in this article are included in the article's Creative Commons licence, unless indicated otherwise in a credit line to the material. If material is not included in the article's Creative Commons licence and your intended use is not permitted by statutory regulation or exceeds the permitted use, you will need to obtain permission directly from the copyright holder. To view a copy of this licence, visit http://creativecommons.org/licenses/by/4.0/.

Publisher's Note Springer Nature remains neutral with regard to jurisdictional claims in published maps and institutional affiliations.

The original article can be found online at https:/ / doi.org/10.1007/s10853-021-05929-8.

Address correspondence to E-mail: j.torres@bucknell.edu 